\title{
Petroleum in Australia.
}

$\mathrm{S}^{0}$ much has been heard in the past concerning $\$$ the prospects of commercial oil supply from indigenous resources of the Commonwealth, that mere mention of the subject is inclined to call forth expressions of scepticism and recollections of past disappointments. But whatever opinion may prevail in technical or financial circles at the moment, perusal of Dr. W. G. Woolnough's report of his tour of inspection of the oilfields of America and Argentina, as bearing on prospects in Australia,* is certainly worth while; if it does not convince in its object, it at least provides a most readable account of the industry in the first two countries, and a very fearless statement of the facts as regards Australia.

The dictum that " nobody but an optimist ever discovered oil " may be taken as the key-word of this report. Dr. Woolnough is clearly an optimist, but his is an optimism based on sober statement of facts, not on extravagant claims. He has toured the Americas widely and has learnt much, as everyone does who makes a similar journey, from the generous insight into the industry which is accorded the visitor. There is scarcely a single phase of the industry which is not discussed or referred to in its bearing on modern practice and tendencies throughout the oil centres of the world, and the author of this report is equally loud in his condemnation of the unsound as he is in praise of the activities which have made the American petroleum industry what it is to-day.

What seems to be needed in Australia, pace past efforts and all that has been written on the subject, is first of all a totally different attitude on the part of the public as a whole towards the actual prospect of finding oil. As in recurrent instances in the history of the American industry, the word petroleum has too often been interpreted in terms of stock-market activities; exploration should be unaccompanied by gambling in shares of companies, the claim of which to assets may only lie in mineral rights or prospecting rights. Exploration for oil needs money (seldom contributed from share funds), patience, up-to-date technique, and first-class initial research. Dr. Woolnough shows that Australians have a great deal to learn in the way of setting about to establish the claim that oil does indeed exist in the continent, and he is clearly impressed with the lessons that can be learnt from American operators.

In some respects it is a pity that this report has come at a time when the financial resources of the country are strained, and when economic conditions generally are against further bold enterprise to probe the question of oil prospects. While the competent geologist, weighing up his claims, may not agree with many of Dr. Woolnough's opinions in a broad way, there is no doubting the sincerity of purpose underlying his estimate of possibilities,

* The Parliament of the Commonwealth of Australia. "Report on Tour of Inspection of the Ofl-Fields of the United Sitates of America and Argentina, and on Oil Prospects in Australia." By Dr. W. G. Woolnough. Pp. 118. (Canberra: H. J. Green, 1931.) 5s. and it would be a thousand pities if, because the moment is inopportune, his work were to be shelved and possibly forgotten. His arguments are interesting. The widespread belief that Australia is geologically too old to contain petroleum, he regards as fallacious. Equally valueless-and here we are at one with him-are the ideas that oil cannot occur commercially south of the equator, other than in tropical regions, and that "there has been a special dispensation of Providence in favour of the United States" in the matter of petroleum supplies. Again, indifferently qualified (and often incompetent) oil men drift from America into Australia, set themselves up as 'experts', from whom come some of the inaccurately worded prospectuses which have in the past misled the public. This sort of thing is checked to some extent in America by protective legislation; it should be similarly checked in the Commonwealth.

Paying tribute to the good work done in Australia in connexion with oil exploration in the past, Dr. Woolnough states quite unequivocally that nowhere does that work approximate in detail or completeness with the ordinary routine in the American oilfields. This is probably correct, but it must be borne in mind that had a really substantial oilfield been discovered in Australia, even by the 'blind stabbing' methods of the old days in the United States, such routine efficiency would have come about automatically, and comparisons would not to-day have been so unfavourable between the methods of the two countries. For what has been wanted, quite apart from a change of attitude of Government and people, has been the actual finding of a good field: in other words, the encouragement which achievement gives. Had there been a really lucky find in the past-the discovery of an oilfield of commercial magnitude comparable with any one of the unit-producing oilfields of the States during the last twenty years-the whole trend of the search for oil in the island continent would have been altered.

Another sidelight on Australian conditions may be quoted verbatim: "It cannot be too strongly insisted that absolute freedom of entry to responsible geologists makes for the most rapid and most economical development of potential oil resources, and that such entry in no way prejudices the interests of the holders of the land. The Australian system of taking up blocks of land without previous survey, and often by the process of marking them off on a map without even visiting the area, would be ludicrous were the effects less tragic." We doubt whether the annals of metalliferous mining history in the continent, wild incidents though they show, can point to more painful examples of that ' getrich-quick' psychology which has proved so detrimental to sound oil exploration in the past.

Then there is the question of adequacy of geological maps. It is not sufficiently widely understood that in order to get the maximum amount of information of geological circumstances, thus

No. 3248 , VoL. 129] 
to lessen cost of drilling in places foredoomed to failure, months (not days) of careful mapping are necessary. The author rightly enjoins his countrymen that there can be no "really wholesome appreciation of the seriousness of oil search " until such ideas are abandoned.

Thus it all comes down to the fact that prospects are still good, given active, honest, and modern methods. The introduction of overseas capital and technique, under proper and stringent safeguards, is urged. Petroleum will not be won by the 'gold-rush' principle, even if it exists in sufficient quantity to justify the optimism of this report, but at the same time it seems probable that unless the Government takes another hand in securing unfettered and co-ordinated research for oil in those parts of the continent where the Survey officers consider the most favourable chances to lie, then private enterprise will have to receive a considerable 'boost', either in the form of new financial resources or tempting technical information, before it will move. But when it comes, whether from national or individual impetus, the problem of oil in Australia will at least have been clarified in its main ethical and technical aspects by the publication of this excellent essay.

\section{Infantile Anæmia and Diet.}

$\mathrm{T}$ HE appearance of a new disease always excites comment, but the disappearance of a common malady may pass without notice. Up to about twenty years ago, a type of simple anæmia, styled 'chlorosis', was prevalent among young employed women in Great Britain : it was easily cured by the administration of iron. To-day, with the improvement in the standard of life of working women, the disease appears to have vanished. Recent investigations have shown, however, that a similar type of anæmia occurs amongst infants, which also can be cured by adding iron to the diet.* The anæmia is of the so-called 'simple' or 'chlo. rotic' type; it is characterised by a marked reduction in the hæmoglobin percentage of the blood, without other changes.

The newborn infant is provided with a store of iron in its liver; about two-thirds of that present in the body at birth is laid down during the last three months of intra-uterine life. Thus the premature infant is born with only a small store, although the amount of iron per kilogram body weight is not much less than that found in the full-term baby. After birth the iron store is drawn upon so that by about six months of age it is no greater than in the adult liver. Milk contains little iron, cow's milk less than human : the chief sources in a diet are meat, eggs, and some green vegetables. Examination of the iron stores of newborn animals of different species has led to the conclusion that when an animal is dependent in its early life upon its mother's milk, the iron required for the formation of the hæmoglobin of its blood is supplied from a store in the liver which is laid down during the later stages of intra-uterine life, while when it is capable of fending for itself soon after birth such a store is unnecessary and is not found. The mammalian organism finds it easier to transfer iron from the mother to the child via the placenta than via the mammary glands and the milk.

A nutritional anæmia can be produced in young animals by an exclusive diet of milk, especially if the parents have been maintained on a diet deficient in iron. In the rat, this anæmia can be cured by

* Medical Researeh Council. Special Report Series, No. 157 Nutritional Anæmia in Infancy: with Special Reference to Iron Deficiency. By Helen M. M. Mackay, assisted by Lorel Goodfellow with a Statistical Appendix by A. Bradford Hill. (Londion : H.M.
Stationery Office, 1931.) 2s. net. No. 3248 , VoL. 129] the administration daily of small doses of iron together with copper. This observation, which appears well substantiated, may explain the contradictory results which have been reported in the treatment of experimental and infantile anæmias by administration of iron salts. This type of anæmia is not due to a vitamin deficiency, nor is it influenced by light treatment.

Dr. Mackay has examined during the past five years 1090 infants and 168 expectant and nursing mothers: the number of hæmoglobin estimations was 4811 on the infants and 315 on the mothers. Part of this work has already been published: the present report refers especially to 174 artificially fed and 230 breastfed infants and 83 mothers. The economic status of the parents of the breastfed babies was slightly better than that of the artificially fed: the fathers were usually small traders or manual workers. The infants were attending the Infant Welfare Department of the Mothers' Hospital of the Salvation Army or the Outpatient Department of the Queen's Hospital for Children. Their ages ranged from $2 \frac{1}{2}$ weeks to 13 months. The artificially fed children were given dried milk with a cane sugar addition, and cod-liver oil and orange juice, up to 8 months of age : the breastfed were also given cod-liver oil and orange juice. Weaning began at about 8 months: thereafter a mixed diet was given to both groups. When iron was given to the artificially fed infants it was supplied as iron and ammonium citrate in the dried milk used ("Hemolac"), $31 \frac{1}{2}$ grains being added to each pound of milk, so that an infant consuming $1 \mathrm{lb}$. of milk in the week received $4 \frac{1}{2}$ grains of the salt daily. The iron salt used contained a trace of copper, and the dried milk also contained traces of copper and manganese: when mixed feeding was instituted the amount of iron and copper in the diet was considerably increased, since most foodstuffs are richer in these elements than milk. The hæmoglobin estimations were made by Haldane's method, the blood being obtained from a prick on the heel.

The hæmoglobin percentage of the untreated, artificially fed infants showed a sharp drop in the first month of life from the high birth value to about sixty-five per cent at $2-3$ months old, a subsequent steady rise to 70 per cent at 5-6 months, and then a continuous drop to 65 per cent at 12 